\title{
Дослідження якості сульфоалітованих покриттів на стальних поверхнях, отриманих методом електроіскрового легування
}

\author{
О.П. Гапонова
}

\author{
Сумський державний університет (м. Суми, Україна) \\ email: gaponova@pmtkm.sumdu.edu.ua
}

\begin{abstract}
Запропонований спосіб сульфоалітування робочих поверхонь екологічно безпечним методом електроіскрового легування, що полягає у нанесенні сірчаної мазі на оброблювану поверхню і подальшого ЕІЛ алюмінієвим електродом. В якості матеріалу підкладки використовували сталь 20 і 40. Після оброблення визначали шорсткість поверхневого шару. Аналіз профілів поверхонь зразків після сульфоалітування методом ЕІЛ і параметрів шорсткості досліджуваних поверхонь показав, що зі збільшенням енергії розряду, а також вмісту вуглецю в сталі параметри Ra, Rz, Rmax зростають. Проведений микроструктурній, дюрометричний та локальний енергодисперсійний аналізи. Металографрічний та дюрометричний аналізи отриманих покриттів показали, що на мікроструктурах можна виділити зони: приповерхневий, не суцільний пухкий шар товщиною 20-40 мкм, зміцнений шар (20-80 мкм), дифузійна зона та основний метал з ферито-перлітною структурою. При заміні матеріалу підкладки зі сталі 20 на сталь 40 збільшується як твердість верхнього шару (1670 і 2240 МПа при енергіях розряду 0,13 і 3,4 Дж відповідно), так і зміцненого шару (5147 і 10380 МПа при енергіях розряду 0,13 і 3,4 Дж відповідно). Зі зростанням енергії розряду збільшуються параметри покриття: товщина, мікротвердість верхнього і зміцненого шару, а також їх суцільність. Локальний енергодисперсійний аналіз показав, що найбільша кількість сірки знаходиться у поверхневому шарі, що характеризує шар зниженої мікротвердості і розподіляється по глибині до 15 мкм. Дифузійна зона алюмінію складає 30-80 мкм, залежно від енергетичних параметрів процесу ЕІЛ. Найбільший вміст алюмінію характерний для ділянок покриття, що знаходяться на відстані 7-15 мкм від поверхні. Приповерхневий пухкий шар збагачений сіркою, зміцнений - алюмінієм.
\end{abstract}

\section{Ключові слова: електроіскрове легування, сірка, алюміній, мікроструктура, шорсткість, сталь}

Вступ. У зв'язку з постійним зростанням режимних параметрів роботи машин і механізмів, крім високих швидкостей і тисків, велика кількість деталей змушені працювати в умовах тертя, агресивних середовищ з високою корозійною та хімічною активністю, екстремальних температур (від високих до кріогенних). Як відомо, гарантією довговічності роботи виробу є не тільки його матеріал і технологія виготовлення, що визначає властивості матеріалу, а й поверхня робочої частини деталі, а точніше - якість поверхні. Створення функціональних поверхневих шарів на робочих поверхнях деталей $€$ економічно вигідним способом підвищення довговічності машин і механізмів.

У літературі представлена широка класифікація покриттів і їх матеріалів за рядом ознак: товщині, міцності зв'язку з підкладкою (основою), матеріалами, функціональними ознаками, способом нанесення і т.д. [1, 2].

У практиці найбільш широкого застосування знайшли такі методи управління якістю поверхневого шару деталі як поверхневе пластичне деформування (обробка дробом, обкатка кулькою, обкатка роликом та ін.) [3, 4], хіміко-термічна обробка (цементація, азотування, нітроцементація й ін.) $[5,6]$, поверхнева термічна обробка (гарту- вання СВЧ, контактна, газополум'янева, в електроліті й ін.) [7], наплавка [8], напилення (PVD, CVD, магнетронне напилення та ін.) [9-10], обробка концентрованими потоками енергії (лазерна, електронним та іонним пучками, електроіскрове легування й ін.).

Постановка проблеми. Аналіз останніх досліджень і публікацій. Аналіз науково-технічної літератури свідчить про те, що в останні роки проводяться роботи по розробці технологій, що можна застосовувати для виробів, що працюють без зовнішнього змащування. Нові можливості в цьому напрямку відкриває метод електроіскрового легування [11]. Відомо, що насичення сіркою поверхонь тертя сприяє підвищенню зносостійкості, покращує припрацьовуваність і протизадирні властивості. Традиційні способи сульфідування, засновані на методі хіміко-термічної обробки, мають недоліки, що стримують їх застосування у виробництві: нагрівання всієї деталі, а відповідно і структурні зміни металу; деформації і викривлення; тривалість процесу до трьох і більше годин; велика витрата електроенергії; негативний вплив на екологію та ін. Відомо, що процес алітування сталевих поверхонь забезпечує підвищення корозійної стійкості та жаростійкості. 
Метод ЕІЛ є одним з найбільш простих і доступних з технологічної точки зору. Серед його переваг необхідно відмітити: локальність, мала втрата енергії, відсутність об'ємного нагрівання матеріалу, висока міцність зчеплення покриття 3 основним металом, необхідно виділити простоту автоматизації процесу, «вбудовуваність» у технологічний процес виготовлення деталей i суміщення операцій, гнучкість процесу за рахунок технологічної уніфікації [12, 13].

Технологічна сутність методу полягає в перенесенні легуючого матеріалу анода на оброблювану поверхню при іскровому розряді в повітряному середовищі [14].

Найбільш важливою особливістю методу ЕІЛ $€$ фрормування змінених поверхневих шарів і покриттів на деталях з різноманітними фізичними $\mathrm{i}$ хімічними властивостями [15]. Варіюючи режимами електроіскрової обробки, складом матеріалів електродів і міжелектродного середовища, можна отримати покриття із заданими експлуатаційними характеристиками.

У [16] запропонований спосіб обробки поверхонь сталевих деталей алюмінієм (алітування) і сіркою (сульфідування) методом електроерозійного легування (те саме, що і ЕІЛ), і може бути застосований для обробки поверхонь термооброблених сталевих деталей. Винахід забезпечує підвищення твердості, зносостійкості, запобігання схоплюванню при терті i поліпшення опору атмосфрерній корозії.

Отже, актуальним $є$ розробка способу отримання двокомпонентного покриття, що містить алюміній та сірку, і забезпечує підвищення твердості та зносостійкості з одночасним зниженням схоплювання поверхонь, що необхідно для деталей пар тертя, які працюють без змащення, методом електроіскрового легування.

Метою роботи $\epsilon$ оцінка якісних параметрів сульфооалітованих покриттів, отриманих методом електроіскрового легування, на стальних поверхнях.

Методика дослідження. Для дослідження використовували зразки зі сталі 20 та 40 (ГОСТ 1050-88) розміром 15×15x8 мм, на які наносили сірчану мазь і здійснювали ЕІЛ алюмінієвим електродом на установці моделі «Элитрон-52A» 3 енергією розряду: $W_{p}=0,13$; 0,55 і 3,4 Дж. В якості електрода використовували стрижні діаметром 4 мм і довжиною 45 мм 3 алюмінієвого дроту марки СвА99 (ГОСТ 7871-75).

Шорсткість поверхні після ЕІЛ вивчали шляхом зняття і обробки профрілограм на приладі профрілографр-профрілометр моделі 201 заводу «Калибр».

Металографічний аналіз покриттів проводили за допомогою оптичного мікроскопа МIM-7, а дюрометричні дослідження - на приладі ПМТ-3 за стандартними методиками.
Для дослідження розподілу елементів і вуглецю по глибині шару використовували скануючий електронний мікроскоп SEO-SEM Inspect S50-B, оснащений енергодисперсійним спектрометром AZtecOne з детектором X-MaxN20 (виробник Oxford Instruments plc).

Результати досліджень. Аналіз отриманих профрілів поверхонь зразків після сульфроалітування методом ЕІЛ і розрахованих за ними параметрів шорсткості досліджуваних поверхонь показує, що параметри: Ra, Rz, Rmax змінюються залежно від енергії розряду, а також від матеріалу основи (рис. 1). Параметри збільшуються В наступному напрямку: зі збільшенням енергії розряду та вмісту вуглецю в сталі основи (табл. 1).
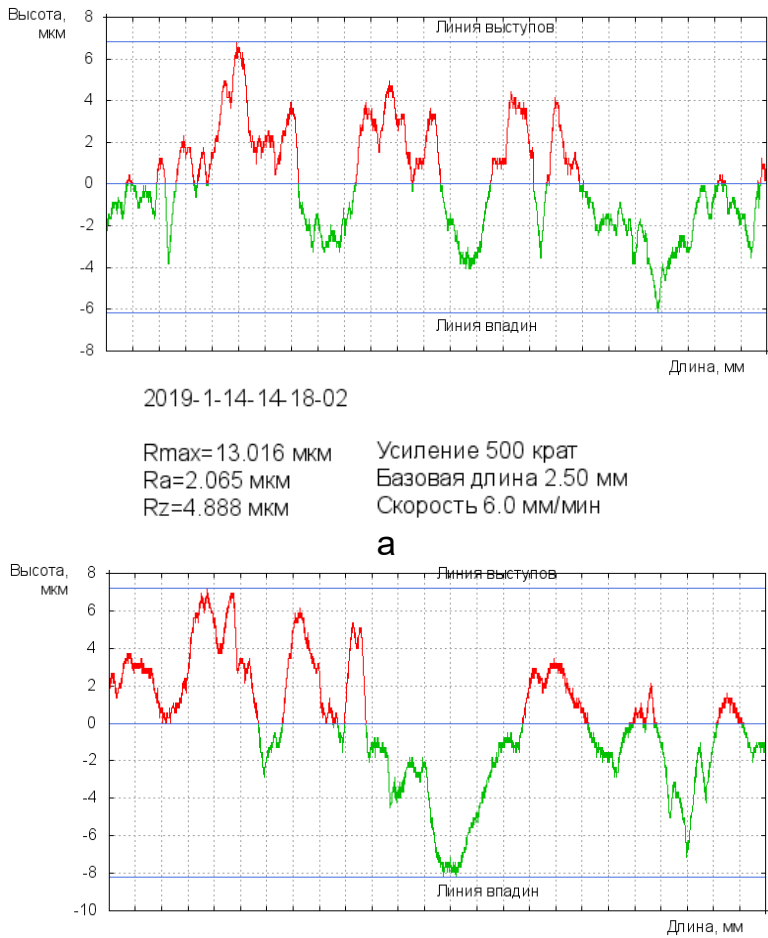

2019-1-14-14-18-02

$$
\begin{array}{ll}
\mathrm{Rmax}=13.016 \mathrm{MkM} & \text { Усиление } 500 \text { крат } \\
\mathrm{Ra}=2.065 \mathrm{MKM} & \text { Базовая длина 2.50 мм } \\
\mathrm{Rz}=4.888 \mathrm{MKM} & \text { Скорость } 6.0 \mathrm{Mм} / \mathrm{Mин} \\
& \text { б }
\end{array}
$$

Рис. 1 Профілограми поверхні зразків після сульфооалітування методом ЕІЛ при $W_{p}=0,55$ Дж: a - сталь 20; б - сталь 40

На рис. 2 представлені мікроструктури зразків зі сталі 20 після сульфоалітування методом ЕІЛ. Проведений металографічний і дюрометричний аналізи свідчать про те, що на мікроструктурах можна виділити чотири зони: приповерхневий, не суцільний пухкий шар, товщиною 2040 мкм і мікротвердістю 1368-2073 МПа, «білий» зміцнений шар товщиною 20-80 мкм і мікротвердістю 4094-7150 МПа, дифузійна зона й основний метал 3 фрерито-перлітною структурою. 
Необхідно відзначити, що зі зростанням енергії розряду збільшуються параметри шару: товщина, мікротвердість верхнього і білого шару, а також їх суцільність (табл. 1).

Таблиця 1. Якісні параметри сульфоалітованих покриттів, отриманих методом ЕІЛ

\begin{tabular}{|c|c|c|c|c|c|c|c|c|c|}
\hline \multirow{2}{*}{ 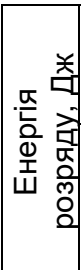 } & \multicolumn{3}{|c|}{$\begin{array}{c}\text { Шорсткість, } \\
\text { мкм }\end{array}$} & \multicolumn{3}{|c|}{$\begin{array}{c}\text { Шар } \\
\text { зниженої } \\
\text { мікротвердості }\end{array}$} & \multicolumn{3}{|c|}{ Зміцнений шар } \\
\hline & $\underset{\widetilde{\simeq}}{\mathscr{\Upsilon}}$ & $\stackrel{N}{\simeq}$ & 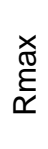 & $\begin{array}{l}\stackrel{0}{\frac{\pi}{\Sigma}} \\
\frac{i}{1}\end{array}$ & $\begin{array}{l}\sum \\
\sum \\
\Sigma\end{array}$ & $\begin{array}{l}\text { ஃீ } \\
\text { ம }\end{array}$ & $\begin{array}{l}\frac{\sigma}{\Sigma} \\
\sum \\
\frac{\Sigma}{1}\end{array}$ & $\begin{array}{l}\sum_{\Sigma} \\
\sum \\
\Sigma\end{array}$ & $\begin{array}{l}\text { ๙0 } \\
\text { ஸ }\end{array}$ \\
\hline \multicolumn{10}{|c|}{ Сталь 20} \\
\hline$\frac{m}{0}$ & $\stackrel{\infty}{0}$ & $\stackrel{m}{\sim}$ & $\begin{array}{l}\infty \\
\sigma^{-}\end{array}$ & $\begin{array}{l}\infty \\
0 \\
\underline{m}\end{array}$ & 웅 & 우 & ষ্ণ & 尺 & R \\
\hline $\begin{array}{l}\text { L } \\
\text { م } \\
0\end{array}$ & $\bar{c}$ & $\underset{\nabla}{\sigma}$ & $m$ & $\begin{array}{l}\mathscr{Q} \\
\mathscr{0}\end{array}$ & ஜ & $\mathscr{6}$ & $\begin{array}{l}\stackrel{2}{\hat{L}} \\
\stackrel{1}{+}\end{array}$ & 요 & $\infty$ \\
\hline$\stackrel{+}{\dot{m}}$ & $\underset{6}{\sim}$ & $\begin{array}{l}\infty \\
\infty \\
\infty\end{array}$ & $\begin{array}{l}\infty \\
\text { o } \\
\end{array}$ & న̊ & న & $\infty$ & $\frac{0}{1}$ & $\infty$ & คి \\
\hline \multicolumn{10}{|c|}{ Сталь 40} \\
\hline$\frac{m}{0}$ & $\stackrel{\sigma}{\sigma}$ & $\stackrel{\bullet}{\sim}$ & $\bar{N}$ & 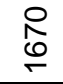 & 웅 & 우 & $\frac{\hat{\sigma}}{50}$ & $\stackrel{\sim}{N}$ & $\stackrel{\llcorner}{N}$ \\
\hline $\begin{array}{l}10 \\
10 \\
0 \\
0\end{array}$ & $\hat{\mathrm{N}}$ & 5 & $\begin{array}{l}\vec{\sigma} \\
\stackrel{0}{\circ}\end{array}$ & 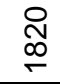 & ஓ & R & $\frac{\stackrel{N}{\sigma}}{\frac{\sigma}{n}}$ & 웅 & ᄋ̊ \\
\hline$\stackrel{+}{\dot{m}}$ & $\bar{\sigma}$ & $\begin{array}{c}\hat{\infty} \\
\stackrel{\infty}{\tau}\end{array}$ & $\begin{array}{l}\infty \\
\infty^{\infty} \\
\prod^{-}\end{array}$ & $\stackrel{\text { ิ }}{\text { N }}$ & প & $\infty$ & $\begin{array}{l}\text { O } \\
\infty \\
\text { గొ } \\
\text { 으 }\end{array}$ & 인 & ది \\
\hline
\end{tabular}

S, \% - суцільність шару

При заміні матеріалу підкладки на сталь 40 збільшується як твердість верхнього шару (1670 і 2240 МПа при енергіях розряду 0,13 і 3,4 Дж відповідно), так і зміцненого шару (5147 і 10380 МПа при енергіях розряду 0,13 і 3,4 Дж відповідно) (рис. 3 та табл. 1). Збільшення мікротвердості зі збільшенням вмісту вуглецю підкладки спостерігалося і при інших процесах легування, наприклад, алітуванні $[17,18]$, сульфоцементації [19]. Очевидно, вплив вмісту вуглецю в основному матеріалі обумовлений формуванням багатофразної гартівної структури.

Електронно-мікроскопічні дослідження свідчать про те, що в результаті сульфоалітування методом ЕІЛ утворюються якісні шари (рис. 4).

На рисунку 5 представлені карти розподілу сірки й алюмінію в сульфоалітованих покриттях, отриманих при різних режимах ЕІЛ. Як показали дослідження, найбільша кількість сірки знаходиться у поверхневому шарі, що характеризує шар зниженої мікротвердості і розподіляється по глибині до 10 мкм. Дифузійна зона алюмінію складає 3080 мкм, залежно від енергетичних параметрів процесу ЕІЛ. Необхідно відзначити, що найбільший вміст алюмінію характерний для ділянок покриття, що знаходяться на відстані 7-15 мкм від поверхні. Отже, приповерхневий «м'який» шар збагачений сіркою, зміцнений - алюмінієм.

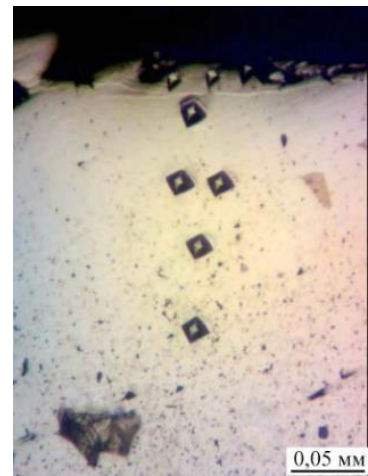

a

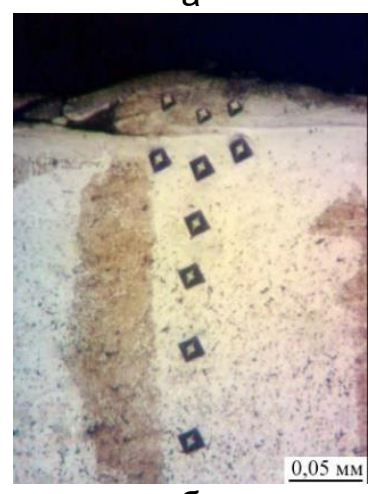

6

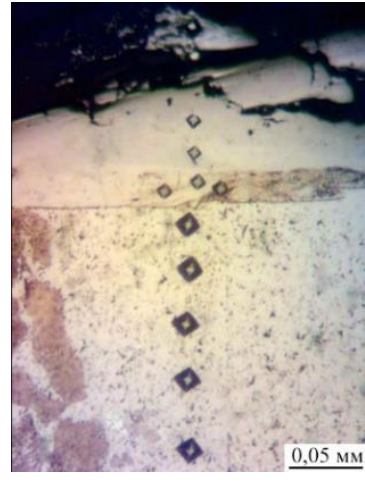

B

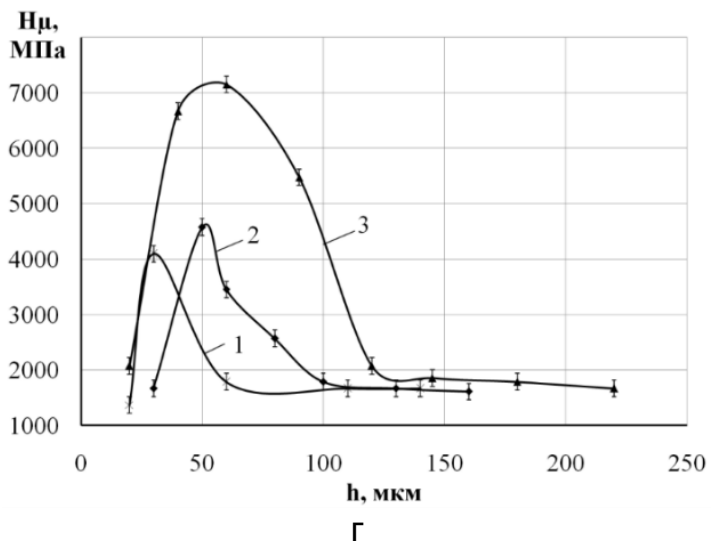

Рис. 2 Мікроструктури (а-в) і розподіл мікротвердості (г) в поверхневому шарі сталі 20 після сульфоалітування методом ЕІЛ:

a) $W_{\mathrm{p}}=0,13$ Дж; б) $W_{\mathrm{p}}=0,55$ Дж;

в) $W_{\mathrm{p}}=3,4$ Дж; г) на графріку: 1) $W_{\mathrm{p}}=0,13$ Дж, 2) $W_{\mathrm{p}}=0,55$ Дж, 3) $W_{\mathrm{p}}=3,4$ Дж 


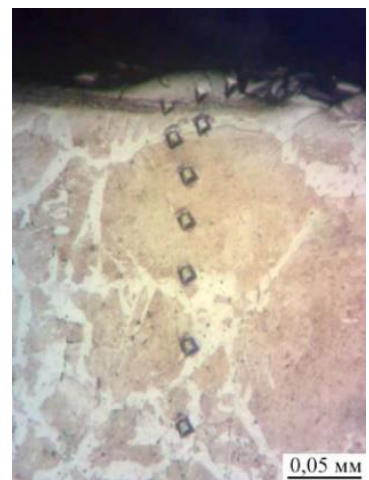

a

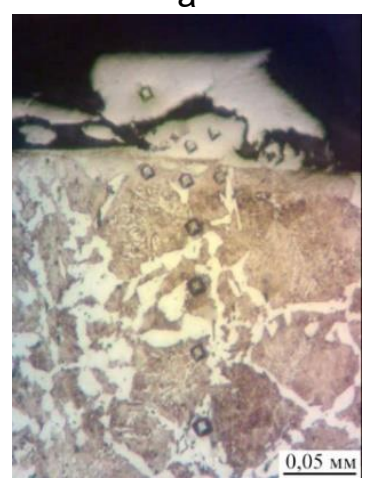

б

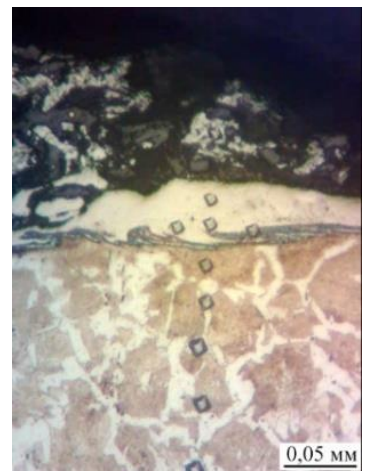

B

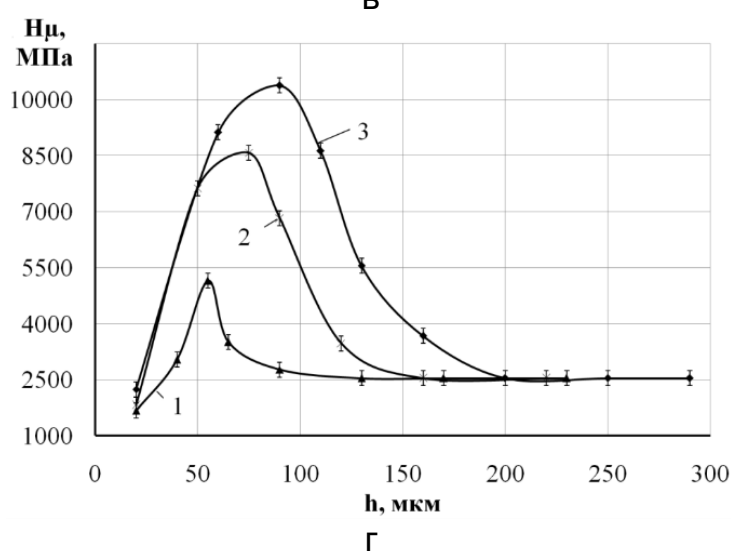

Рис. 3 Мікроструктури (а-в) і розподіл мікротвердості (г) в поверхневому шарі сталі 40 після сульфоалітування методом ЕІЛ:

a) $W_{\mathrm{p}}=0,13$ Дж; б) $W_{\mathrm{p}}=0,55$ Дж;

в) $W_{\mathrm{p}}=3,4$ Дж; г) на графріку: 1) $W_{\mathrm{p}}=0,13$ Дж,

$$
\text { 2) } W_{\mathrm{p}}=0,55 \text { Дж, 3) } W_{\mathrm{p}}=3,4 \text { Дж }
$$

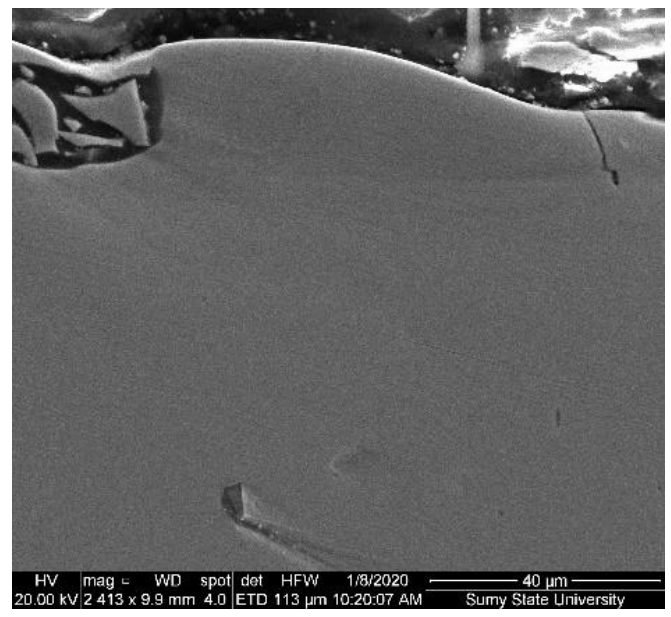

a

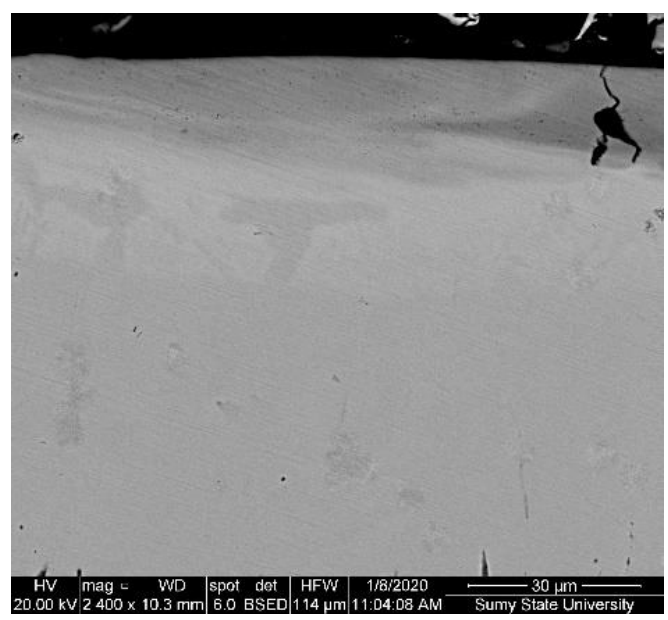

6

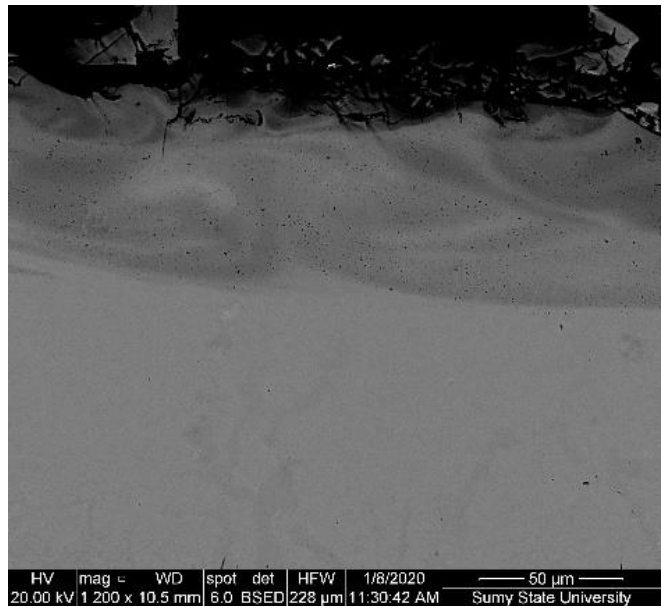

B

Рис. 4 Структури поверхневих шарів сталі 40 після сульфоалітування методом ЕІЛ: $\mathrm{a}-W_{\mathrm{p}}=0,13$ Дж; $\sigma-W_{\mathrm{p}}=0,55$ Дж; $\mathrm{B}-W_{\mathrm{p}}=3,4$ Дж
ISSN 2311-1828

http://enm.khntusg.com.ua
Інженерія природокористування, 2020, №3(17), с. 86 - 93

Engineering of nature management, 2020, \#3(17), p. 86 - 93 


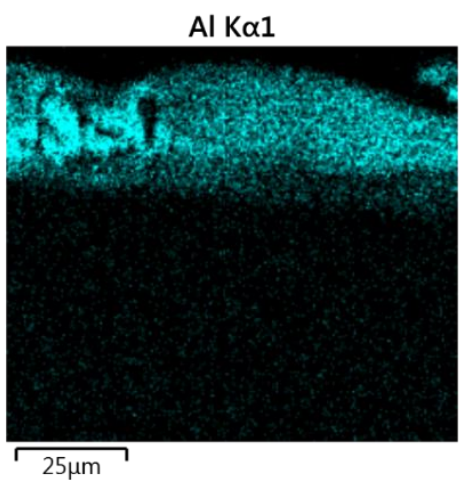

a

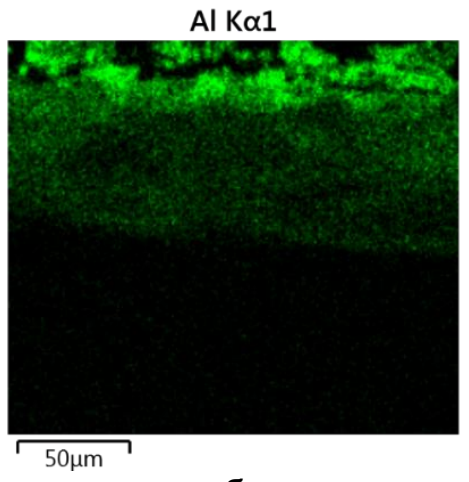

6

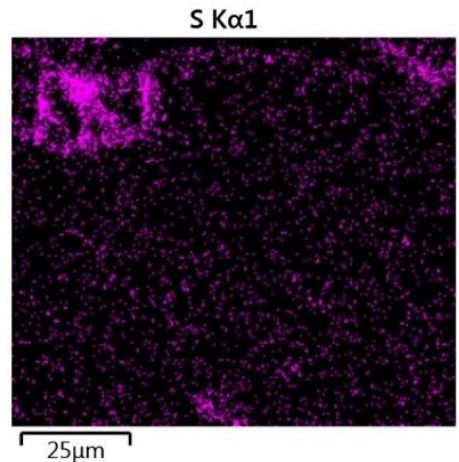

B

S K $\alpha 1$

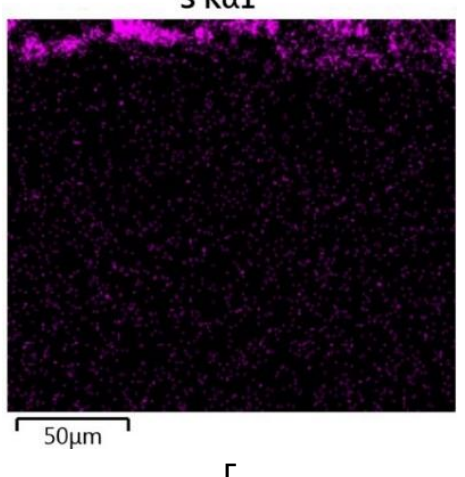

Рис. 5 Карти розподілу хімічних елементів в покритті після сульфоалітування сталі 40 методом ЕІЛ з різною енергією розряду: a, в $-W_{\mathrm{p}}=0,13$ Дж; б, г- $W_{\mathrm{p}}=3,4$ Дж

\begin{tabular}{|c|c|c|c|c|c|c|c|c|c|}
\hline \multirow{2}{*}{ 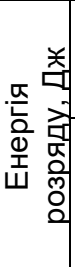 } & \multicolumn{3}{|c|}{$\begin{array}{c}\text { Шорсткість, } \\
\text { мкм }\end{array}$} & \multicolumn{3}{|c|}{$\begin{array}{c}\text { Шар } \\
\text { зниженої } \\
\text { мікротвердості }\end{array}$} & \multicolumn{3}{|c|}{ Зміцнений шар } \\
\hline & $\underset{\mathscr{\mathbb { x }}}{\mathscr{0}}$ & $\stackrel{N}{\simeq}$ & 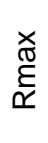 & $\begin{array}{l}\underset{\mathbb{0}}{\Sigma} \\
\frac{5}{I}\end{array}$ & $\begin{array}{l}\sum_{\sum} \\
\sum \\
\Sigma\end{array}$ & $\begin{array}{l}\circ \\
\text { क }\end{array}$ & $\begin{array}{l}\stackrel{\sigma}{\Sigma} \\
\sum \\
\frac{\Sigma}{\Sigma}\end{array}$ & $\begin{array}{l}\sum \\
\sum \\
\Sigma\end{array}$ & $\begin{array}{l}\circ \\
\text { ஸ }\end{array}$ \\
\hline \multicolumn{10}{|c|}{ Сталь 20} \\
\hline$\frac{m}{0}$ & $\stackrel{\infty}{\sigma^{-}}$ & $\stackrel{m}{\sim}$ & $\stackrel{\infty}{\omega}$ & $\begin{array}{l}\infty \\
0 \\
\text { m- } \\
\end{array}$ & 웅 & 유 & ষ্ণ & ㅇ & r \\
\hline $\begin{array}{l}100 \\
\text { L } \\
0\end{array}$ & $\bar{c}$ & $\stackrel{\infty}{\forall}$ & $\stackrel{m}{\square}$ & $\begin{array}{l}0 \\
\mathbb{E} \\
0\end{array}$ & ஜి & $\mathscr{6}$ & $\begin{array}{l}\frac{10}{5} \\
\frac{10}{4}\end{array}$ & ஜి & ${ }_{\infty}^{\infty}$ \\
\hline $\begin{array}{l}\vec{\nabla} \\
\text { ஸे }\end{array}$ & $\underset{6}{\sim}$ & $\begin{array}{l}\infty \\
\infty \\
\infty\end{array}$ & \begin{tabular}{l}
$\infty$ \\
$\infty$ \\
\multirow{+}{*}{}
\end{tabular} & ָ̃ & ণ & $\infty$ & $\begin{array}{l}0 \\
\frac{1}{1} \\
\end{array}$ & $\infty$ & o \\
\hline \multicolumn{10}{|c|}{ Сталь 40} \\
\hline$\frac{m}{0}$ & g) & $\stackrel{\bullet}{\sim}$ & $\pi$ & $\begin{array}{l}R \\
0 \\
T\end{array}$ & 움 & 유 & 守 & ㅇ & $\frac{1}{1}$ \\
\hline $\begin{array}{l}10 \\
10 \\
0\end{array}$ & $\hat{\sim}$ & $\bar{\sigma}$ & $\begin{array}{l}\forall \\
\stackrel{8}{\circ}\end{array}$ & 尺્N & 요 & ㅇ & $\frac{\stackrel{N}{N}}{\sigma}$ & 우 & ৪ \\
\hline$\stackrel{+}{m}$ & $\bar{\sigma}$ & $\begin{array}{l}\hat{\infty} \\
\infty^{-}\end{array}$ & $\begin{array}{l}\infty \\
\infty \\
\infty\end{array}$ & 온 & ஜ & $\infty$ & $\begin{array}{l}\text { 이 } \\
\text { ల } \\
\text { O }\end{array}$ & 옷 & "ू \\
\hline
\end{tabular}

Висновки. Аналіз профрілів поверхонь зразків після сульфоалітування методом ЕІЛ і параметрів шорсткості досліджуваних поверхонь показав, що зі збільшенням енергії розряду, а також вмісту вуглецю в сталі параметри Ra, Rz, Rmax зростають. Металографічний та дюрометричний аналізи отриманих покриттів на сталі 20 свідчать про те, що на мікроструктурах можна виділити чотири зони: приповерхневий, не суцільний пухкий шар, товщиною 20-40 мкм і мікротвердістю 1368$2073 \mathrm{MПа,} \mathrm{«білий»} \mathrm{зміцнений} \mathrm{шар} \mathrm{товщиною} \mathrm{20-}$ 80 мкм і мікротвердістю 4094-7150 МПа, дифузійна зона й основний метал з ферито-перлітною структурою. Необхідно відзначити, що зі зростанням енергії розряду збільшуються параметри шару: товщина, мікротвердість верхнього і білого шару, а також їх суцільність. При заміні матеріалу підкладки на сталь 40 збільшується як твердість верхнього шару (1670 і 2240 МПа при енергіях розряду 0,13 і 3,4 Дж відповідно), так і зміцненого шару (5147 і 10380 МПа при енергіях розряду 0,13 і 3,4 Дж відповідно). Локальний енергодисперсійний аналіз показав, що найбільша кількість сірки знаходиться у поверхневому шарі, що характеризує шар зниженої мікротвердості i розподіляється по глибині до 15 мкм. Дифузійна зона алюмінію складає 30-80 мкм, залежно від енергетичних параметрів процесу ЕІЛ. Найбільший вміст алюмінію характерний для ділянок покриття, що знаходяться на відстані 7-15 мкм від поверхні. Приповерхневий «м'який» шар збагачений сіркою, зміцнений - алюмінієм. 


\section{Література}

1. Современные технологии модификации поверхности материалов и нанесения защитных покрытий: в 3 т. / АО «Машиностроит. конструкт. бюро «Искра» им. И. И. Картукова» (г. Москва) [и др.]. - Санкт-Петербург : Реноме, 2017.

2. Інженерія поверхні : Підруч. / К. А. Ющенко, Ю. С. Борисов, В. Д. Кузнецов, В. М. Корж; НАН України. Ін-т електрозварювання ім. Є.О.Патона. - К.: Наук. Думка, 2007. - 559 с.

3. Тамаркин М.А. Исследование параметров качества поверхностного слоя при обработке дробью / М.А. Тамаркин, Э.Э. Тищенко, В.Г. Лебеденко. // Вестник машиностроения, 2010. - № 2. - С. 51-54.

4. Лихобабина Н. В. Упрочнение поверхностей алмазным выглаживанием / Н. В. Лихобабина, А. А. Королев. // Вестник Саратовского государственного технического университета, 2008. - T. 1. - № 1(30). - С. 17-24.

5. Ворошнин Л. Г., Менделеева О.Л., Сметкин В.А. Теория и технология химико-термической обработки. Учебное пособие. - Минск: Новое знание, 2010. -304 с.

6. Довгань Л.В. Анализ технологий вакуумной и атмосферной химико-термической обработки металлов / Л.В. Довгань. // Металлургия машиностроении, 2008. - № 1. - С. 29-33.

7. Патент РФ 2153007, 2000.

8. Шехтер С.Я. Наплавка металлов / С.Я. Шехтер, А.М. Резницкий. - М.: Машиностроение, 1982. - 72 c.

9. Структура, свойства и получение твердых нанокристаллических покрытий, осаждаемых несколькими способами / В. М. Береснев, А. Д. Погребняк, Н. А. Азаренков, Г. В. Кирик, Н. К. Ердыбаева, В. В. Понарядов. // Успехи фииз. мет., 2007. - T. 8. - C. 171-246.

10. Pogrebnjak O.D. Features of thermodynamic processes on contact surfaces of multicomponent nanocomposite coatings with hierarchical and adaptive behaviour // O.D., Pogrebnjak, K.O. Dyadyura, O.P. Gaponova. // Metallofiz. Noveishie Tekhnol., 2015. - Vol. 37. - No. 7. - P. 899-919. https://doi.org/10.15407/mfint.37.07.0899

11. Екологічна безпека експлуатації компресорного і насосного обладнання : монографрія / В. А. Марцинковський, В. Б. Тарельник, Б. Антошевський та ін. / за ред. О. В. Родіонова. - Суми: СумДУ, 2018. - 282 с.

12. Тарельник В. Б. Управление качеством поверхностных слоев деталей комбинированным электроэрозионным легированием / В. Б. Тарельник. - Сумы: МакДен, 2002. - 323 с.

13. К вопросу создания нового научного направления в области электроэрозионной обработки - электродного материаловедения /
А.Д. Верхотуров, И.А. Подчерняева, В.И. Иванов, Л.А. Коневцов. // Электронная обработка материалов, 2010. - № 5. - С. 145-155.

14. Цементация электроэрозионным легированием : монография / В.Б. Тарельник, Б. Антошевский, В.С. Марцинковский и др.; под ред. проф. В.Б. Тарельника. - Сумы: Университетская книга, 2015. - 233 с.

15. Электроискровые технологии восстановления и упрочнения деталей машин и инструментов (теория и практика) / Ф.Х. Бурумкулов, П.П. Лезин, П.В. Сенин, В.И. Иванов, С.А. Величко, П.А. Ионов. - Саранск: МГУ им. Н.П. Огарева, 2003. - 504 c.

16. Патент UA 121343, 2020.

17. Estimating qualitative parameters of aluminized coating obtained by electric spark alloying method. / O. Gaponova, C. Kundera, G. Kirik, V. Tarelnyk, V. Martsynkovskyy, I. Konoplianchenko, M. Dovzhyk, A. Belous, O. Vasilenko // Advances in Thin Films, Nanostructured Materials, and Coatings. NAP 2018. Lecture Notes in Mechanical Engineering. Springer Nature Singapore Pte Ltd., 2019. - p. 249266. https://doi.org/10.1007/978-981-13-6133-3_25

18. Quality Analysis of Aluminized Surface Layers Produced by Electrospark Deposition. / G.V. Kirik, O.P. Gaponova, V.B. Tarelnyk, O.M. Myslyvchenko, B. Antoszewski. // Powder Metallurgy and Metal Ceramics, 2018. - Vol. 56. - Issue 11-12. - P. 688-696. https://doi.org/10.1007/s11106-018-9944-6

19. Патент UA 130866, 2018.

\section{References}

1. Sovremennyye tekhnologii modifikatsii poverkhnosti materialov i naneseniya zashchitnykh pokrytiy: v 3 t (2017). Moskva - Sankt-Peterburg : Renome.

2. Yushchenko, K. A. et al. (2007) Inzheneriya poverkhni. Kyiv: Nauk. Dumka. 559 p.

3. Tamarkin, M.A., Tishchenko, E.E., Lebedenko, V.G. (2010) "Issledovaniye parametrov kachestva poverkhnostnogo sloya pri obrabotke drob'yu," Vestnik mashinostroyeniya, (2), pp. 51-54.

4. Likhobabina, N. V., Korolev, A. A. (2008) "Uprochneniye poverkhnostey almaznym vyglazhivaniyem," Vestnik Saratovskogo gosudarstvennogo tekhnicheskogo universiteta, (T. 1., 1(30)), pp. 17-24.

5. Voroshnin, L. G. et al. (2010) Teoriya i tekhnologiya khimiko-termicheskoy obrabotki: uchebnoye posobiye. Minsk: Novoye znaniye. 304 p.

6. Dovgan, L.V. (2008) "Analiz tekhnologiy vakuumnoy i atmosfernoy khimiko-termicheskoy obrabotki metallov," Metallurgiya mashinostroyenii, (1), pp. 29-33.

7. Patent RF 2153007, 2000. 
8. Shekhter, S.Ya., Reznitskiy, A.M. (1982) Naplavka metallov. Moskva: Mashinostroyeniye. $72 \mathrm{p}$.

9. Beresnev, V. M. et al. (2007) "Struktura, svoystva i polucheniye tverdykh nanokristallicheskikh pokrytiy, osazhdayemykh neskol'kimi sposobami," Uspekhi fiz. met., (T. 8.), pp. 171-246.

10. Pogrebnjak, O.D., Dyadyura, K.O., Gaponova, O.P. (2015) "Features of thermodynamic processses on contact surfaces of multicomponent nanocomposite coatings with hierarchical and adaptive behaviour," Metallofiz. Noveishie Tekhnol., (Vol. 37, 7), pp. 899-919. https://doi.org/10.15407/mfint.37.07.0899

11. Martsynkovs'kyy, V. A. et al. (2018) Ekolohichna bezpeka ekspluatatsiyi kompresornoho i nasosnoho obladnannya : monohrafiya. Sumy : SumDU. $282 \mathrm{p}$.

12. Tarel'nik V. B. (2002) Upravleniye kachestvom poverkhnostnykh sloyev detaley kombinirovannym elektroerozionnym legirovaniyem. Sumy: MakDen. 323 p.

13. Verkhoturov, A.D. et al. (2010) "K voprosu sozdaniya novogo nauchnogo napravleniya $v$ oblasti elektroerozionnoy obrabotki - elektrodnogo materia- lovedeniya," Elektronnaya obrabotka materialov, (5), pp. $145-155$.

14. Tarel'nik V.B. et al. (2015) Tsementatsiya elektroerozionnym legirovaniyem : monografiya. Sumy: Universitetskaya kniga. 233 p.

15. Burumkulov, F.Kh. et al. (2003) Elektroiskrovyye tekhnologii vosstanovleniya i uprochneniya detaley mashin i instrumentov (teoriya $\mathrm{i}$ praktika). Saransk: MGU im. N.P. Ogareva. 504 p.

16. Patent UA 121343, 2020.

17. Gaponova O. et al. (2019) "Estimating qualitative parameters of aluminized coating obtained by electric spark alloying method", Advances in Thin Films, Nanostructured Materials, and Coatings. NAP 2018. Lecture Notes in Mechanical Engineering. Springer Nature Singapore Pte Ltd., pp. 249-266. https://doi.org/10.1007/978-981-13-6133-3_25

18. Kirik, G.V. et al. (2018) "Quality Analysis of Aluminized Surface Layers Produced by Electrospark Deposition," Powder Metallurgy and Metal Ceramics, (Vol. 56, 11-12), pp. 688-696. https://doi.org/10.1007/s11106-018-9944-6

19. Patent UA 130866, 2018.

\section{Аннотация}

\section{Исследование качества сульфоалитированных покрытий на стальных поверхностях, полученных методом электроискрового легирования}

\section{О.П. Гапонова}

Предложен способ сульфоалитирования рабочих поверхностей экологически безопасным методом электроискрового легирования, заключающийся в нанесении серной мази на обрабатываемую поверхность и последующего ЭИЛ алюминиевым электродом. В качестве материала подложки использовали сталь 20 и 40. После обработки определяли шероховатость поверхностного слоя. Анализ профилей поверхностей образцов после сульфоалитирования методом ЭИЛ и шероховатости исследуемых поверхностей показал, что с увеличением энергии разряда, а также содержания углерода в стали, параметры Ra, Rz, Rmax возрастают. Проведенный микроструктурный, дюрометрический и локальный энергодисперсионный анализы. Металлографический и дюрометрический анализы полученных покрытий показали, что на микроструктурах можно выделить зоны: приповерхностный, не сплошный рыхлый слой толщиной 20-40 мкм, упрочненный слой (20-80 мкм), дифффузная зона и основной металл с феррито-перлитной структурой. При замене материала подложки со стали 20 на сталь 40 увеличивается как твердость верхнего слоя (1670 и 2240 МПа при энергиях разряда 0,13 и 3,4 Дж, соответственно), так и упрочненного слоя (5147 и 10380 МПа при энергиях разряда 0,13 и 3,4 Дж, соответственно). С ростом энергии разряда увеличиваются параметры покрытия: толщина, микротвердость верхнего и упрочненного слоя, а также их сплошность. Локальный энергодисперсионный анализ показал, что наибольшее количество серы находится в поверхностном слое, характеризующего слой пониженной микротвердости и распределяется по глубине до 15 мкм. Дифффузная зона алюминия составляет 3080 мкм, в зависимости от энергетических параметров процесса ЭИЛ. Наибольшее содержание алюминия характерно для участков покрытия, находящихся на расстоянии 7-15 мкм от поверхности. Приповерхностный рыхлый слой обогащен серой, упрочненный - алюминием.

Ключевые слова: электроискровое легирование, сера, алюминий, микроструктура, шероховатость, сталь 


\section{Abstract \\ Investigation of the quality of sulfoalitizing coatings on steel surfaces obtained by electrospark alloying method}

\section{O.P. Gaponova}

The method sulfoalitizing of work surfaces by an environmentally friendly method of electrospark alloying is proposed. The method is comprised of applying sulphur ointment to the surface and subsequent ESA by an aluminium electrode. Steels 20 and 40 were used as the substrate materials. After processing, the roughness of the surface layer was determined. Analysis of the surface profiles of the samples after sulfoalitizing by EIL and the roughness parameters of the studied surfaces is showed that parameters $R a, R z, R$ max are increased with increasing discharge energy, as well as the carbon content in the steel. Microstructural, durometric and local energy dispersive analyses are carried out. Metallographic and durometric analyses of the obtained coatings are showed zones on microstructures: a near-surface, not continuous loose layer with thickness of 20-40 $\mu \mathrm{m}$, a hardened layer $(20-80 \mu \mathrm{m})$, diffusion zone and a base metal with a ferrite-pearlite structure. Replacing the substrate material from steel 20 to steel 40 the hardness of the upper layer (1670 and $2240 \mathrm{MPa}$ at discharge energies of 0.13 and $3.4 \mathrm{~J}$, respectively) and of the reinforced layer (5147 and $10380 \mathrm{MPa}$ at discharge energies of 0.13 and $3.4 \mathrm{~J}$ respectively) are increased. The parameters of the coating thickness, microhardness, continuity are increased with an increase discharge energy. Local energy dispersion analysis is showed that the sulfur is concentrated in the surface layer, which characterized the layer of reduced microhardness and is distributed at a depth of up to $15 \mu \mathrm{m}$. The diffusion zone of aluminum is $30-80 \mu \mathrm{m}$, depending on the energy parameters of the EIL process. The aluminum is concentrated on coating areas located at a distance of 7-15 $\mu \mathrm{m}$ from the surface. The near-surface layer is enriched with sulfur, the hardened layer is aluminium.

Keywords: electrospark alloying, sulphur, aluminium, microstructure, roughness, steel

Бібліографічне посилання/ Bibliography citation: Harvard

Gaponova, O. P. (2020) 'Investigation of the quality of sulfoalitizing coatings on steel surfaces obtained by electrospark alloying method', Engineering of nature management, (3(17), pp. 86 - 93.

Подано до редакції / Received: 06.09.2020 